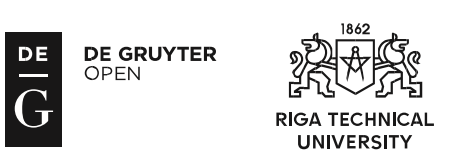

\title{
A COMPARISON OF THE APPROACHES TO CUSTOMER EXPERIENCE ANALYSIS
}

\author{
David HAVÍŘ \\ Brno University of Technology, Czech Republic \\ Corresponding author e-mail: david.havir@vutbr.cz
}

\begin{abstract}
Nowadays, customer experience is receiving much attention in scientific and managerial community. Scholars and practitioners state that customer experience is the next area of competition. For a long time, there has been a call for a uniform, accurate definition, definition of its components, and the development of the customer experience frameworks. As this topic is new, there has been a considerable fragmentation. The question is if the fragmentation is still present and how can we address it.

The aim of this paper is to summarize research on customer experience analysis and to explore and compare the dimensions describing customer experience listed in seven conceptual models with findings from 17 research projects on customer experience conducted after the year 2010. The purpose of this is to summarize recent knowledge, get the most comprehensive view on customer experience and its possible decomposition, and to reveal possible relationships between the dimensions.

Based on a review of the available literature, the paper juxtaposes several approaches to customer experience analysis and compares their results to find similarities and differences among them. In the first step, the dimensions and factors of the customer experience were extracted from the seven models to analyze customer experience and they were compared with each other. This resulted in a set of dimensions and factors. In the next step, customer experience factors and dimensions were extracted from 17 practical research papers on customer experience. Finally, based on their descriptions and found similarities, the dimensions and factors were put together into several groups, as this grouping and creation of the new universal set of dimensions might solve the fragmentation issue.
\end{abstract}

Keywords: Customer experience (CX), dimensions, research methods, scale development.

JEL Classification: M31.

\section{INTRODUCTION}

The phenomenon of customer experience is considered as the new direction of focus in the area of marketing. While the goods and services are becoming commoditized, the experiences provided to costumers are considered so unique that they create the next level for differentiation and the new field for competitive battles too (Badgett et al., 2007; Bolton et al., 2014; Meyer \& Schwager, 2007; Reinartz \& Ulaga, 2008; Schmitt, 2003). Experience management improves trust, customer satisfaction, loyalty, financial performance, and influences customers' behavior 
across the range of contexts, quality and duration of the relationship between brand and customer (Ballester \& Aleman, 2001; Britton \& Rose, 2004; Demangeot \& Broderick, 2006; Hardyman et al., 2015; Klaus, 2011; Klaus \& Maklan, 2012; Nguyen et al., 2014; Klaus, 2014a; Moorman et al., 1992). Aware of all that, managerial and scientific community is trying to understand the experience (Frow \& Payne, 2007; Johnston \& Kong, 2011; Klaus, 2014b; Klaus \& Maklan, 2013; Lemke et al., 2011; McColl-Kennedy et al., 2015; Schouten et al., 2007). They are analyzing the whole process from the creation of experience, its measurement, mapping the outcomes to its improvement (Voss et al., 2008). However, several problems were identified through years, such as the lack of the definition of the customer experience, the lack of corresponding measurements, and the lack of complex customer experience framework (Maklan \& Klaus, 2011). The main problem remained the same, and it is related to how companies view the customer experience (Klaus, 2013a).

The crucial prerequisite of analyzing customer experience is the ability to take the role of a customer. But the companies are still struggling to leave their business process view and, instead, to adopt the customers' perception of customer journey. Thus, they are not able to understand the customers' roles and customers' cognitive, affective, emotional, social, physical responses and, worse, they can't affect these results in the desired way or co-create the experience with the customer (Bolton et al., 2014; Cho \& Park, 2001; Gentile et al., 2007; Jones \& Sasser, 1995; Laming \& Mason, 2014; McColl-Kennedy et al., 2012; Payne et al., 2008; Schmitt, 1999; Verhoef et al., 2009).

Based on this shortage in customer experience management, several researchers developed methods and frameworks for making customers' language more understandable for the managerial sphere (Parasuraman et al., 1988, 2005; Wolfinbarger \& Gilly, 2003; Fornerino, 2006; Gentile et al., 2007; Verhoef et al., 2009; Klaus \& Maklan, 2012).

\section{CONCEPTUAL MODELS AND THEIR DIMENSIONS}

As customer experience is in the focus of scholars for more than five years, several research projects on customer experience analysis were conducted. Some of the authors used SERVQUAL as their guide for analyzing customer experience; however, this approach was found inappropriate because of its limitations to fully capture the complexity of customer experience (Sureshchandar et al., 2002; Ladhari, 2009), because it focuses only on analyzing the gap between expectations and actual delivery (Parasuraman et al., 1988). On the other hand, SERVQUAL proved to be universal enough to be valid and reliable across a wide range of service contexts (Maklan Klaus, 2011).

Researchers tried to establish new standards for measuring the customer experience (Wolfinbarger \& Gilly, 2003; Gentile et al., 2007; Verhoef et al., 2009; Klaus \& Maklan, 2012). Some models reflected the rise of the e-commerce, some build upon old approaches with the intention to deepen the understanding of customers' perception. Hence, the dimensions of some models are more concrete 
and focused on the customer as an emotional human being, some are, on the other hand, focused on the process of acquiring goods or services.

\section{METHODS AND PROCEDURES}

Within the exploratory research, a review of the available literature on customer experience models and practical research projects is used for the extraction of dimensions for their later comparison.

\subsection{Exploration of Conceptual Models}

The set of seven models was selected as the most mentioned, cross-referenced or unique models that represent gradual development in this field, especially their key dimensions through which they perceive customer experience. SERVQUAL (Parasuraman et al., 1988) model was chosen because of its universality (Maklan \& Klaus, 2011), the weight other researchers give to it, and because it is the oldest model used by researchers while analyzing customer experience. E-S-QUAL model (Parasurman et al., 2005) was then chosen, because it is considered as an improved version of SERVQUAL, ready for technological and online world. Another model reflecting these changes in the global market and so chosen for the comparison is eTailQ (Wolfinbarger \& Gilly, 2003). Consumption experience model (Fornerino, 2006) was chosen because of its unique focus on the experience while consuming art and because of its influence on the next chosen model called Customer experience model (Gentile et al., 2007). This model and Conceptual model of customer experience (Verhoef et al., 2009) were chosen because they were used by Klaus \& Maklan (2012) for comparison with their new EXQ model. And EXQ model was chosen because it is the most recent result of the scientific effort to come up with the appropriate framework or model to customer experience analysis. During the model selection, emphasis was put on their date of publication to be evenly spread over time.

\subsection{SERVQUAL Model}

There are five dimensions of SERVQUAL scale (Parasuraman et al., 1988). The first one is reliability representing the ability of the provider to reliably and accurately deliver a service that he promised to the customer, which involves, for example, keeping promises related to the delivery, pricing, or complaint handling. The second one is responsiveness, in other words, the willingness to help customers, to provide prompt service and the attitude of personnel towards customer complaints, requests, and questions. The third dimension of SERVQUAL scale is assurance, the overall ability to build the trust and confidence between the company and the customer. The next one, empathy, evaluates individual approach and the attention the company provides to each customer. And the fifth dimension, tangibility, contains the appearance of all the elements that represent the service in the physical form (e. g., facilities, equipment, personnel). 


\subsection{TailQ Experience Model}

Wolfinbarger \& Gilly (2003) in response to the growing phenomenon of ecommerce developed the four-item scale for measuring customer experience in the online environment. The first item of four is website design, which includes all the elements at the website that can influence customer's experience, such as navigation style, information search, ordering process, or personalization. Fulfillment/reliability dimension evaluates the accuracy of the description of the product on the website and the delivery of the right product at the promised time. The next dimension is the customer service, which should be quick, responsive, and helpful. The fourth dimension, security/privacy, is based on the security of payments and the privacy of all shared information.

\subsection{E-S-QUAL Model}

Parasuraman et al. (2005) also reacted on the popularity of e-commerce and modified accordingly their SERVQUAL scale. The result is a new four-dimensional scale called E-S-QUAL. The first dimension is efficiency covering the ease and speed of accessing and using the website. Fulfillment reflects the credibility of the information about availability and delivery date and the degree to which they are fulfilled. System availability is all about correct technical functioning of the website. The last privacy dimension evaluates the safety of the website and how company handles and protects the customer's personal information.

\subsection{Consumption Experience Model}

Fornerino (2006) in his research analyzed customer experience from the perspective of the attendees of the concert and the viewers of the movie. He also identified five basic dimensions of customer experience perception. The first dimension called sensorial/perceptual is the dimension that reflects the stimulation of senses. Affective dimension references to the moments of strong emotions, excitement, joy, pleasure, or sadness. The third, called physical/behavioral, describes the visible manifestations aroused by the most intense moments. Social is the next dimension that relates to the interaction, even the communion, with other people (friends but also unknown). The last one is the cognitive dimension containing thoughts produced during the event whether they are related to it.

\subsection{Customer Experience Model}

Gentile et al. (2007), drawing on passing literature, created a model with six main dimensions of customer experience. Sensorial dimension, simply put, contains everything that affects the senses. The aim of elements within this dimension is to provide good sensorial experience through sight, hearing, touch, taste, smell to arise, for example, excitement, satisfaction, or esthetic pleasure. Emotional dimension is based on influencing the moods, feelings, and emotions to create an emotional relation with the company, brand, or its products. The third, cognitive dimension, incorporates customer's thinking and conscious mental processes. To influence experience from the cognitive perspective, the company may engage its 
customers by using their creativity, problem solving abilities, or lead them to revise their ideas and expectations. Pragmatic dimension is closely connected with the act of doing something in practice and the concept of usability. Through the lifestyle dimension, the company affirms shared values and beliefs with the customer through the product, its consumption, and use. The sixth, relational dimension, derives from customer's social context, relationship with other people, and his ideals. To influence experience from this point of view, the company can through its products encourage the customers to use or consume together, to create the communities of fans or make the customers feel sense of belonging to a social group or community.

\subsection{Conceptual Model of Customer Experience}

Verhoef et al. (2009) developed a conceptual model of customer experience creation based on the prior re-search. The first dimension in this model is social environment. This dimension is based on customer-to-customer interactions, for example, customers' interactions with other customers in retail space, interactions with family, or friends shopping with the customer. The second, service interface, is similar to the first one but with the difference that it stands on the interactions between the customer and company employees (e. g., retail staff, service personnel). Retail atmosphere dimension consists of all aspects of the retail such as in-store music, color of the interior, placement of the equipment, etc. Assortment represents the ability of the company to provide a wide range of different, unique and quality products. Price dimension consists of all the benefits the company can pro-vide, from loyalty programs, personalized promotions to customized products. Customer experience is nowadays perceived from the multi-channel perspective, and so the experience of one channel can have an impact on the experience in another channel. This fact is captured by the sixth dimension called customer experiences in alternative channels. The last dimension, retail brand, takes into account that customers in many cases buy products from one brand in the store of another brand and so the resulting experience is determined by the experience provided by both these brands.

\subsection{EXQ Framework}

In 2012, Klaus \& Maklan (2012) published a paper where they conceptualize and validate their own method for measuring the customer experience called EXQ. From the wide variety of sub-dimensions, they defined four main dimensions that influence overall perceived experience. The first dimension, product experience, advocates that customers want to have an opportunity to choose from a range of products and to have ability to compare different offerings. The dimension of the outcome focus is based on reducing the customers' transaction costs (e. g., searching for new providers). The moments of truth reflect the quality and the flexibility of the service that company provides to the customer once any complications arise. The fourth dimension, peace of mind, represents all the customer's appraisals, mainly of emotional character, of his whole customer journey. 


\subsection{Dimensions of Customer Experience Models}

Table 1 summarizes the customer experience dimensions of the models above. Although some of the models also describe many sub-dimensions, only the main dimensions were chosen for better comparison of the models.

Table 1. Overview of the dimensions of customer experience models

\begin{tabular}{|c|c|c|c|c|c|c|}
\hline \begin{tabular}{|l|} 
SERVQUAL \\
model \\
(Parasuraman \\
et al., 1988)
\end{tabular} & $\begin{array}{c}\text { eTailQ } \\
\text { experience } \\
\text { (Wolfinbar } \\
\text { ger \& } \\
\text { Gilly, } \\
\text { 2003) }\end{array}$ & $\begin{array}{l}\text { E-S-QUAL } \\
\text { (Parasurama } \\
\text { n et al., 2005) }\end{array}$ & $\begin{array}{c}\text { Consumption } \\
\text { experience } \\
\text { model } \\
\text { (Fornerino, } \\
\text { 2006) }\end{array}$ & $\begin{array}{c}\text { Customer } \\
\text { experience } \\
\text { model } \\
(\text { Gentile } \text { et } \\
\text { al., 2007) }\end{array}$ & $\begin{array}{c}\text { Conceptual } \\
\text { model of } \\
\text { customer } \\
\text { experience } \\
\text { (Verhoef } e t \\
\text { al., 2009) }\end{array}$ & $\begin{array}{c}\text { EXQ } \\
\text { framework } \\
\text { (Klaus \& } \\
\text { Maklan, } \\
\text { 2012) }\end{array}$ \\
\hline Reliability & $\begin{array}{l}\text { Website } \\
\text { design }\end{array}$ & Efficiency & $\begin{array}{l}\text { Sensorial/ } \\
\text { Perceptual }\end{array}$ & Sensorial & $\begin{array}{c}\text { Social } \\
\text { environment }\end{array}$ & $\begin{array}{c}\text { Product } \\
\text { experience }\end{array}$ \\
\hline Responsiveness & $\begin{array}{l}\text { Fulfillment/ } \\
\text { Reliability }\end{array}$ & Fulfillment & Affective & Emotional & $\begin{array}{l}\text { Service } \\
\text { interface }\end{array}$ & $\begin{array}{l}\text { Outcome } \\
\text { focus }\end{array}$ \\
\hline Assurance & $\begin{array}{l}\text { Security/ } \\
\text { Privacy }\end{array}$ & $\begin{array}{l}\text { System } \\
\text { availability }\end{array}$ & $\begin{array}{l}\text { Physical/ } \\
\text { Behavioral }\end{array}$ & Cognitive & $\begin{array}{l}\text { Retail } \\
\text { atmosphere }\end{array}$ & $\begin{array}{l}\text { Moments of } \\
\text { truth }\end{array}$ \\
\hline Empathy & $\begin{array}{l}\text { Customer } \\
\text { service }\end{array}$ & Privacy & Social & Pragmatic & Assortment & $\begin{array}{l}\text { Peace of } \\
\text { mind }\end{array}$ \\
\hline \multirow[t]{3}{*}{ Tangibility } & & & Cognitive & Lifestyle & Price & \\
\hline & & & & Relational & \begin{tabular}{|l|} 
Customer \\
experiences \\
in \\
alternative \\
channels \\
\end{tabular} & \\
\hline & & & & & Retail brand & \\
\hline
\end{tabular}

\subsection{Similarities in Dimensional Decomposition}

In the description of the dimensions and the table above, we can find several similarities. The reliability, assurance, fulfillment, and system availability dimensions from SERVQUAL, eTailQ, and E-S-QUAL models are all about building trust between the company and the customer. The website design, efficiency, pragmatic, and outcome focus dimensions from eTailQ, E-S-QUAL, Customer experience models, and EXQ framework have a common aspect of the ease of use. The responsiveness, customer service, service interface, and moments of truth dimensions from SERVQUAL, eTailQ, Conceptual model of customer experience, and EXQ framework share the factor of service that company/employees provide to customers. The affective, emotional, and peace of mind dimension present in Consumption experience, Customer experience models, and EXQ framework are built upon the perception of the consumer as a human being with emotions. The social, relational, and social environment dimensions 
from Consumption experience model, Customer experience model, and Conceptual model of customer experience are connected through social context and influence of other people on the customer. Tangibility, website design and retail atmosphere from SERVQUAL, eTailQ, and Conceptual model of customer experience are referencing to the environment in which the customer makes a purchase or related pre- and post-activities.

\subsection{Exploration of Research Projects}

After 2010, more than a dozen of scholar research projects on customer experience consisting of dimensional decomposition were conducted, mostly in Europe and Asia. Table 2 creates a summary of 17 of them with the additional information about the methods of data collection and data analysis, industry/field, year of publishing, and country of data collection. From this set of papers, used or observed dimensions and factors of customer experience will be later extracted as was done in the case of conceptual models.

Table 2. Overview of approaches and methods to analyse customer experience with additional information

\begin{tabular}{|c|c|c|c|c|c|c|}
\hline & \multirow[t]{2}{*}{ Author } & \multicolumn{2}{|c|}{ Methods } & \multirow{2}{*}{$\begin{array}{l}\text { Industry/ } \\
\text { field }\end{array}$} & \multirow{2}{*}{$\begin{array}{c}\text { Year of } \\
\text { publishing }\end{array}$} & \multirow{2}{*}{$\begin{array}{c}\text { Country of } \\
\text { data } \\
\text { collection }\end{array}$} \\
\hline & & Data collection & Data analysis & & & \\
\hline 1 & $\begin{array}{l}\text { Chang \& Horng } \\
(2010)\end{array}$ & Questionnaire & $\begin{array}{l}\text { EFA, } \\
\text { Cronbach's } \\
\text { alpha, CFA }\end{array}$ & $\begin{array}{l}\text { Clothing \& } \\
\text { accessories, } \\
\text { food \& } \\
\text { beverage }\end{array}$ & 2010 & Taiwan \\
\hline 2 & $\begin{array}{l}\text { Maklan \& Klaus } \\
\qquad(2011)\end{array}$ & $\begin{array}{l}\text { Soft laddering } \\
\text { interview }\end{array}$ & $\begin{array}{c}\text { EFA, CFA, } \\
\text { IFI, CFI, SEM }\end{array}$ & Banking & 2011 & UK \\
\hline 3 & $\begin{array}{c}\text { Sirapracha \& } \\
\text { Tocquer (2012) }\end{array}$ & Questionnaire & $\begin{array}{c}\text { EFA, } \\
\text { Cronbach's } \\
\text { alpha, } \\
\text { MANOVA, } \\
\text { ANOVA }\end{array}$ & $\begin{array}{l}\text { Telecommu- } \\
\text { nication }\end{array}$ & 2012 & Thailand \\
\hline 4 & Rose et al. (2012) & $\begin{array}{c}\text { Online } \\
\text { questionnaire }\end{array}$ & $\begin{array}{l}\text { SEM, } \\
\text { Cronbach's } \\
\text { alpha }\end{array}$ & $\begin{array}{l}\text { Online } \\
\text { shopping }\end{array}$ & 2012 & $\begin{array}{l}\text { USA, } \\
\text { Europe }\end{array}$ \\
\hline 5 & $\begin{array}{c}\text { Wijaithammarit \& } \\
\text { Taechamaneestit } \\
\text { (2012) }\end{array}$ & Questionnaire & $\begin{array}{l}\text { Cronbach's } \\
\text { alpha, SEM, } \\
\text { Path analysis }\end{array}$ & $\begin{array}{l}\text { Supercenter } \\
\text { shopping }\end{array}$ & 2012 & Thailand \\
\hline 6 & $\begin{array}{c}\text { Badgare \& Jain } \\
\text { (2013) }\end{array}$ & $\begin{array}{l}\text { Informal } \\
\text { interview }\end{array}$ & $\begin{array}{l}\text { EFA, } \\
\text { Cronbach's } \\
\text { alpha, CFA }\end{array}$ & Multiple & 2013 & India \\
\hline
\end{tabular}




\begin{tabular}{|c|c|c|c|c|c|c|}
\hline & Author & Metl & hods & Industry/ & Year of & Country of \\
\hline & & Data collection & Data analysis & & & \\
\hline 7 & Klaus et al. (2013) & $\begin{array}{l}\text { Soft laddering } \\
\text { interview }\end{array}$ & \begin{tabular}{|c|} 
EFA, CFA, \\
IFI, CFI, SEM
\end{tabular} & Banking & 2013 & Italy \\
\hline 8 & $\begin{array}{l}\text { Klaus \& Maklan } \\
\text { (2013) }\end{array}$ & $\begin{array}{l}\text { Online and } \\
\text { printed } \\
\text { questionnaire }\end{array}$ & $\begin{array}{c}\text { EFA, CFA, } \\
\text { SEM }\end{array}$ & Multiple & 2013 & UK \\
\hline 9 & Klaus (2013b) & $\begin{array}{l}\text { Soft laddering } \\
\text { interview }\end{array}$ & $\begin{array}{l}\text { Exploratory } \\
\text { research, ECT }\end{array}$ & Online retail & 2013 & $\begin{array}{l}\text { UK, USA, } \\
\text { Sweden }\end{array}$ \\
\hline 10 & Garg et al. (2014) & Questionnaire & $\begin{array}{l}\text { EFA, } \\
\text { Cronbach's } \\
\text { alpha, CFA }\end{array}$ & $\begin{array}{l}\text { Retail } \\
\text { banking }\end{array}$ & 2014 & India \\
\hline 11 & $\begin{array}{c}\text { Chauhan \& Manhas } \\
\text { (2014) }\end{array}$ & Questionnaire & $\begin{array}{c}\text { EFA, } \\
\text { Cronbach's } \\
\text { alpha, } \\
\text { ANOVA, } \\
\text { comparative } \\
\text { analysis }\end{array}$ & Aviation & 2014 & India \\
\hline 12 & Balaji et al. (2015) & Online survey & $\begin{array}{c}\text { EFA, CFA, } \\
\text { SEM }\end{array}$ & $\begin{array}{c}\text { Media } \\
\text { consumption }\end{array}$ & 2015 & International \\
\hline 13 & Shim et al. (2015) & Online survey & $\begin{array}{c}\text { EFA, CFA, } \\
\text { MANOVA, } \\
\text { ANOVA, SEM }\end{array}$ & \begin{tabular}{|c|} 
Online \\
shopping on \\
the apparel \\
website
\end{tabular} & 2015 & International \\
\hline 14 & $\begin{array}{l}\text { Menachem et al. } \\
\text { (2015) }\end{array}$ & Questionnaire & $\begin{array}{l}\text { EFA, } \\
\text { Cronbach's } \\
\text { alpha, CFA }\end{array}$ & $\begin{array}{c}\text { Telecommu- } \\
\text { nication }\end{array}$ & 2015 & India \\
\hline 15 & $\begin{array}{l}\text { Chahal and Dutta } \\
\qquad(2015)\end{array}$ & Questionnaire & $\begin{array}{l}\text { EFA, } \\
\text { Cronbach's } \\
\text { alpha, CFA }\end{array}$ & Banking & 2015 & India \\
\hline 16 & $\begin{array}{c}\text { Stein \& Ramaseshan } \\
\text { (2016) }\end{array}$ & $\begin{array}{l}\text { Semi-structure } \\
\text { interview }\end{array}$ & $\begin{array}{l}\text { SIT, inductive } \\
\text { thematic } \\
\text { analysis, cross- } \\
\text { case analysis }\end{array}$ & Multiple & 2016 & Australia \\
\hline 17 & Kashif et al. (2016) & Questionnaire & $\begin{array}{l}\text { Harman's one- } \\
\text { factor test, } \\
\text { CFA, SEM }\end{array}$ & Healthcare & 2016 & Malaysia \\
\hline
\end{tabular}

\section{RESULTS}

There are dozens of differently named dimensions, but most of them can be categorized into the dimensional groups defined by the models from Chapter 1. For example, outcome focus, efficiency, interactive speed, ease of use, perceived control and benefits, usability convenience, online functional elements, speed, comfort, interface usability, navigation and technological dimensions can be, based 
on their definitions, clustered together. Service providers, moments of truth, customer service, satisfaction of employees, service experience, employees, recognition, service, customer care, employee-customer interaction can together create another cluster. Third cluster can be composed of other customers, customers' companions, connectedness, social presence, presence of other customers, relational and communicative dimensions. Customers themselves, peace of mind, mood and affective dimensions are also very similar to each other. Price, customization, sale promotions, value for money, interactivity can be considered as the basis for the next cluster. Dimensions sharing the next cluster are the ones called physical surroundings, atmosphere, context familiarity, servicescape, store/gallery $\&$ self-service, and atmospheric. Trust, communication, reliability and billing create the next one. Product-oriented cluster is formed by product experience, packaging, distinct, remote features, watch, network. There are also two small clusters. The first consists of lifestyle and behavioral dimensions, and the second one consists of product presence and sensory dimensions.

But there are also present new dimensions that cannot be simply clustered with the dimensions from Chapter 1. One such cluster includes dimensions called brand, brand experience, and brand image. Then there is the cluster of telepresence, joy, leisure, online hedonic elements, and hedonism. The third cluster groups aesthetics and online aesthetics. Core service and core dimension create the fourth cluster. The fifth cluster comprises the service process and process dimensions.

Some dimensions are too universal, lack sufficient description, or unique so they can't be clearly clustered with other dimensions from other research projects. These dimensions are: challenge, skill, merchandise, product availability, accessibility, advertising, service mix, post purchase experience, marketing mix, customer interaction, value addition, novelty, safety, and intellect

\section{DISCUSSION AND CONCLUSION}

Secondary research of papers aimed at analyzing customer experience shows that, continuously through the years, several models that reacted on the changes in market environment emerged. There is also already a significant amount of practical research projects from different industries. Most of the authors use the dimensions of customer experience devised for their specific research. Only a tiny portion precisely reflects any of the models. This gives rise to the hypothesis that there is the existence of fragmentation in the dimensional decomposition of customer experience. Although there has long been a call for unification in the field of customer experience, it seems that it has not happened yet. On the other hand, it allowed the authors to describe customer experience in a much richer way. Despite this, their descriptions of dimensions suggest that they overlap each other and so might be grouped into less than sixteen clusters. This number is only rough, and the possibility of clustering needs to be verified by further research based on more advanced research methods. As the result, a new scale of dimensions could be developed while maintaining a richer descriptive potential gained through the analysis of customer experience research papers from Chapter 2 . This could help to define the scale that could be enough rich to be used in most research projects, and 
it could also help non-scientific sphere to better understand the dimensions of customer experience.

An interesting finding is that the dimensions related to user experience seem very similar to the dimensions found in customer experience, just applied in the virtual world. This creates the next hypothesis that the dimensions of user experience are similar to the dimensions of customer experience. It might be valuable to verify this correlation, and possibly analyze and incorporate the knowledge from more user experience research projects. Nowadays, the user experience plays an increasingly bigger role in the overall customer experience. In addition, this could indicate to the need for closer cooperation between customer experience and user experience departments and, thus, be a new factor of the success for companies in the world where experience is the main differentiator.

\section{ACKNOWLEDGMENT}

This research is part of the project "Specific business success factors in the Czech Republic" led by Ing. Peter Kita (FP-J-17-4254).

\section{REFERENCES}

Badgett, M., Boyce, S. M., \& Kleinberger, H. (2007). Turning Shoppers into Advocates. Somers, NY: IBM Institute for Business Value. Retrieved from www.ibm.com

Bagdare, S., \& Jain, R. (2013). Measuring retail customer experience. International Journal of Retail \& Distribution Management, 41(10), 790-804. https://doi.org/10.1108/ijrdm-08-2012-0084

Balaji, T. S., Arumugham, J., Knuycky, L., Cavrak, S., \& Lutz, M. (2015). Structural Equation Modeling In User Experience Research: Two Case Studies. Proceedings of the Human Factors and Ergonomics Society Annual Meeting, 59(1), 448-452. https://doi.org/10.1177/1541931215591095

Ballester, E. D., \& Aleman, J. L. M. (2001). Brand trust in the context of consumer loyalty. European Journal of Marketing, 35(11/12), 1238-1258. https://doi.org/10.1108/eum0000000006475

Bolton, R. N., Gustafsson, A., McColl-Kennedy, J. R., Sirianni, N. J., \& Tse, D. K. (2014). Small details that make big differences: a radical approach to consumption experience as a firm's differentiating strategy. Journal of Service Management, 25(2), 253-274. https://doi.org/10.1108/josm-01-2014-0034

Britton, J. E., \& Rose, J. (2004). Thinking about relationship theory. In P. D. Rogers, M. Rogers (Eds.), Managing Customer Relationships - A Strategic Framework, John Wiley and Sons, NJ, 38-50.

Chahal, H., \& Dutta, K. (2015). Measurement and impact of customer experience in banking sector. Decision, 42(1), 57-70. https://doi.org/10.1007/s40622-014-0069-6

Chang, T.-Y., \& Horng, S.-C. (2010). Conceptualizing and measuring experience quality: the customer's perspective. The Service Industries Journal, 30(14), 2401-2419. https://doi.org/10.1080/02642060802629919

Chauhan, V., \& Manhas, D. (2014). Dimensional Analysis of Customer Experience in Civil Aviation Sector. Journal of Services Research, 14(1), 75-98. Retrieved from www.jsr-iimt.in

Cho, N., \& Park, S. (2001). Development of electronic commerce user-consumer satisfaction index (ECUSI) for internet shopping. Industrial Management and Data Systems, 101(8), 400-406. https://doi.org/10.1108/eum0000000006170

Demangeot, C., \& Broderick, A. J. (2006). Exploring the experential intensity of online shopping environments. Qualitative Market Research: An International Journal, 9(4), 325-351. https://doi.org/10.1108/13522750610689078

Frow, P., \& Payne, A. (2007). Towards the 'perfect' customer experience. Journal of Brand Management, 15(2), 89-101. https://doi.org/10.1057/palgrave.bm.2550120

Fornerino, M., Helme-Guizon, A., \& de Gaudemaris, C. (2006). Mesurer L'immersion dans une experience de consommation: Premiers developpements, Proceedings of the XXIIth Congress de l'AFM, France. Retrieved from www.afm-marketing.com

Garg, R., Rahman, Z., \& Qureshi, M. N. (2014). Measuring customer experience in banks: scale development and validation. Journal of Modelling in Management, 9(1), 87-117. https://doi.org/10.1108/jm2-07-2012$\underline{0023}$ 
Gentile, C., Spiller, N., \& Noci, C. (2007). How to sustain the customer experience: an overview of experience components that co-create value with the customer. European Management Journal, 25(5), 395-410. https://doi.org/10.1016/j.emj.2007.08.005

Hardyman, W., Daunt, K. L., \& Kitchener, M. (2015). Value co-creation through patient engagement in health care: a micro-level approach and research agenda. Public Management Review, 17(1), 90-107. https://doi.org/10.1080/14719037.2014.881539

Johnston, R., \& Kong, X. (2011). The customer experience: a road-map for improvement. Managing Service Quality: An International Journal, 21(1), 5-24. https://doi.org/10.1108/09604521111100225

Jones, T., \& Sasser, W. E. (1995). Why satisfied customers defect. Harvard Business Review, 73(11/12), 8899. Retrived from www.hbr.org

Kashif, M., Samsi, S. Z. M., Awang, Z., \& Mohamad, M. (2016). EXQ: measurement of healthcare experience quality in Malaysian settings: A contextualist perspective. International Journal of Pharmaceutical and Healthcare Marketing, 10(1), 27-47. https://doi.org/10.1108/ijphm-03-2015-0011

Klaus, P. (2011). Quo Vadis, Customer Experience? In C. Rusconi (ed.), Beyond CRM: Customer Experience in the Digital Era. Strategies, Best Practices and Future Scenarios in Luxury and Fashion, Milano: Franco Angeli, 165-175.

Klaus, P., \& Maklan, S. (2012). EXQ: a multiple-item scale for assessing service experience. Journal of Service Management, 23(1), 5-33. https://doi.org/10.1108/09564231211208952

Klaus, P. (2013a). Preservers, Transformers \& Vanguards: Measuring the Profitability of Customer Experience Strategies. Design Management Review, 24(4). https://doi.org/10.1111/drev.10260

Klaus, P. (2013b). The case of Amazon.com: towards a conceptual framework of online customer service experience (OCSE) using the emerging consensus technique (ECT). Journal of Services Marketing, 27(6), 443-457. https://doi.org/10.1108/jsm-02-2012-0030

Klaus, P., Gorgoglione, M., Buonamassa, D., Panniello, U., \& Nguyen, B. (2013). Are you providing the 'right' customer experience? The case of Banca Popolare di Bari. International Journal of Bank Marketing, 31(7), 506-528. https://doi.org/10.1108/ijbm-02-2013-0019

Klaus, P., \& Maklan, S. (2013). Towards a better measure of customer experience. International Journal of Market Research, 55(2), 227-21. https://doi.org/10.2501/ijmr-2013-021

Klaus, P. (2014a). Measuring Customer Experience: How to Develop and Execute the Most Profitable Customer Experience Strategies. London: Palgrave-Macmillan.

Klaus, P. (2014b). Towards practical relevance - Delivering superior firm performance through digital customer experience strategies. Journal of Direct, Data and Digital Marketing Practice, 15(4), 306-316. https://doi.org/10.1057/dddmp.2014.20

Ladhari, R. (2009). A review of twenty years of SERVQUAL research. International Journal of Quality and Service Sciences, 1(2), 172-198. https://doi.org/10.1108/17566690910971445

Laming, C., \& Mason, K. (2014). Customer experience - An analysis of the concept and its performance in airline brands. Research in Transportation Business and Management, 10, 15-25. https://doi.org/10.1016/j.rtbm.2014.05.004

Lemke, F., Clark, M., \& Wilson, H. (2011). Customer experience quality: an exploration in business and consumer contexts using repertory grid technique. Journal of Academy of Marketing Science, 39(6), 846869. https://doi.org/10.1007/s11747-010-0219-0

Maklan, S., \& Klaus, P. (2011). Customer experience: are we measuring the right things? International Journal of Market Research, 53(6), 771. https://doi.org/10.2501/ijmr-53-6-771-792

McColl-Kennedy, J. R., Gustafsson, A., Jaakkola, E., Klaus, P., Radnor, Z. J., Perks, H., \& Friman, M. (2015). Fresh perspectives on customer experience. The Journal of Services Marketing, 29(6/7), 430-435. https://doi.org/10.1108/jsm-01-2015-0054

McColl-Kennedy, J. R., Vargo, S. L., Dagger, T. S., Sweeney, J. C., \& van Kasteren, Y. (2012). Health Care Customer Value Cocreation Practice Styles. Journal of Service Research, 15(4), 370-389. https://doi.org/10.1177/1094670512442806

Menachem, D., Joshi, S., Bhatia, S., Roy, A., \& Saini, J. (2015). An Empirical Study to Measure Customer Experience for Telecom Operators in Indian Telecom Industry. GSTF Journal on Business Review (GBR), 4(2), 45-52. https://doi.org/10.7603/s40706-015-0020-7

Meyer, C., \& Schwager, A. (2007). Understanding customer experience. Harvard Business Review, 85(2), 11626. Retrieved from www.hbr.org

Moorman, C., Zaltman, G., \& Deshpande, R. (1992). Relationships between providers and users of market research: the dynamics of trust within and between organizations. Journal of Marketing Research, 29(3), 314-328. https://doi.org/10.2307/3172742

Nguyen, B., Klaus, P., \& Simkin, L. (2014). It's just not fair: exploring the effects of firm customization on unfairness perceptions, trust and loyalty. The Journal of Services Marketing, 28(6), 497-484. https://doi.org/10.1108/jsm-05-2013-0113 
Parasuraman, A., Zeithaml, Valerie A., \& Berry, Leonard L. (1988). SERVQUAL: a multiple-item scale for measuring consumer perceptions of service quality. Journal of Retailing, 64(1), 12-40. Retrieved from www.journals.elsevier.com

Parasuraman, A., Zeithaml, V. A., \& Malhotra, A. (2005). E-S-QUAL: A Multiple-Item Scale for Assessing Electronic Service Quality. Journal of Service Research, 7(3), 213-233. Retrieved from www.journals.sagepub.com

Payne, A. F., Storbacka, K., \& Frow, P. (2008). Managing the co-creation of value. Journal of the Academy of Marketing Science, 36(1), 83-96. https://doi.org/10.1007/s11747-007-0070-0

Reinartz, W., \& Ulaga, W. (2008). How to sell services more profitably. Harvard Business Review, 86(5), 906. Retrieved from www.hbr.org

Rose, S., Clark, M., Samouel, P., \& Hair, N. (2012). Online Customer Experience in e-Retailing: An empirical model of Antecedents and Outcomes. Journal of Retailing, 88(2), 308-322. https://doi.org/10.1016/j.jretai.2012.03.001

Schmitt, B. H. (1999). Experiential Marketing. New York: The Free Press.

Schmitt, B. H. (2003). Customer experience management: A revolutionary approach to connecting with your customers. New York: Wiley.

Schouten, J. W., McAlexander, J. H., \& Koenig, H. F. (2007). Transcendent customer experience and brand community. Journal of the Academy of Marketing Science, 35(3), 357-368. https://doi.org/10.1007/s11747-007-0034-4

Shim, S. I., Forsythe, S., \& Kwon, W.-S. (2015). Impact of Online Flow on Brand Experience and Loyalty. Journal of Electronic Commerce Research, 16(1), 56-71. Retrieved from www.jecr.org

Sirapracha, J., \& Tocquer, G. (2012). Branding and Customer Experience in the Wireless Telecommunication Industry. International Journal of Trade, Economics and Finance, 3(2), 103-108. https://doi.org/10.7763/ijtef.2012.v3.181

Stein, A., \& Ramaseshan, B. (2016). Towards the identification of customer experience touch point elements. Journal of Retailing and Consumer Services, 30, 8-19. https://doi.org/10.1016/j.jretconser.2015.12.001

Sureshchandar, G., Rajendran, C., \& Anantharaman, R. (2002). The relationship between management's perception of total quality service and customer perceptions of service quality. Total Quality Management, 13(1), 69-88. https://doi.org/10.1080/09544120120098573

Verhoef, P. C., Lemon, K. N., Parasuraman, A., Roggeveen, A., Tsiros, M., \& Schlesinger, L. A. (2009). Customer Experience Creation: Determinants, Dynamics and Management Strategies. Journal of Retailing, 85(1), 31-41. https://doi.org/10.1016/j.jretai.2008.11.001

Voss, C., Roth, A. V., \& Chase, R. B. (2008). Experience, service operations strategy, and services as destinations: foundations and exploratory investigation. Production and Operations Management, 17(3), 247-266. https://doi.org/10.3401/poms.1080.0030

Wijaithammarit, S., \& Taechamaneestit, T. (2012). The Impact of Customer Experience Management on Customer Loyalty of Supercenter's Shopper in Thailand. International Journal of E-Education, E-Business, E-Management and E-Learning, 2(6). https://doi.org/10.7763/ijeeee.2012.v2.166

Wolfinbarger, M., \& Gilly, M. C. (2003). eTailQ: dimensionalizing, measuring and predicting etail quality. Journal of Retailing, 79(3), 183-198. https://doi.org/10.1016/s0022-4359(03)00034-4

\section{AUTHORS' SHORT BIOGRAPHY}

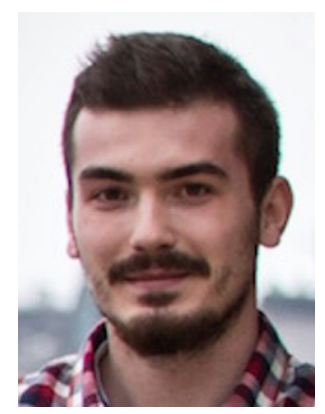

David Havír received the Bachelor's degree in managerial informatics in 2014, and Master's degree in information management in 2016. D. Havír is currently a Ph.D. student in company management and economics at Brno University of Technology, Czech Republic. He is planning, managing and controlling the research and development projects at the Project Management Office of the Aerospace Division of Honeywell International, s.r.o at Brno, Czech Republic. Before, he was analysing data and designing user interface at the same company. His current research areas include customer experience, user experience, strategic marketing, customer behaviour, and sharing economy.

Email: david.havir@vutbr.cz 